\title{
Urgensi Dan Penanaman Nilai-Nilai Sejarah
}

\author{
Rahmat Fadillah \\ Email: 1810111110018@mhs.ulm.ac.id \\ Program Studi Pendidikan Sejarah Fakultas Keguruan dan Ilmu Pendidikan \\ Universitas Lambung Mangkurat \\ Banjarmasin
}

\begin{abstract}
Abstrak
Secara hakikatnya nasionalisme itu sendiri tiada lain kecuali bersumber dari sejarah. Manusia berperan dalam sejarah, bahkan juga sebagai pembuat sejarah itu sendiri, hal ini karena manusia lah yang membuat pengalaman menjadi sejarah. Manusia juga adalah penutur sejarah yaitu pelaku yang membuat cerita sejarah atau sumber sejarah. Dan yang penting untuk dipahami adalah bahwa kisah manusia dibatasi oleh waktu, ruang dan tempat manusia itu berada.
\end{abstract}

\section{PENDAHULUAN}

Setiap bangsa yang di bumi ini memiliki sejarah nya masing-masing walaupun terdapat beberapa negara yang belum sempat mengabadikan sejarahnya. Dengan cara kita mempelajari sejarah, maka sama dengan kita mengenali diri sendiri. Namun sebaliknya pula, ketika kita melupakan sejarah, maka sama saja dengan orang yang kehilangan ingatannya. Sejarah itu sendiri merupakan petunjuk mengenai apa dan siapa manusia itu sebenarnya. Sejarah merupakan pengalaman dan ingatan dari manusia yang kemudian diceritakan dimasa yang akan datang, manusia yang berperan dalam sejarah itu sendiri yaitu sebagai pembuat sejarah. Cerita manusia dibatasi oleh waktu, ruang dan tempat di mana manusia itu berada. Pemahaman mengenai ruang dan waktu sangatlah diperlukan agar dapat mengembangkan kemampuan berpikir secara kronologis.

\section{MASA KINI ADALAH HASIL DARI MASA LAMPAU}

Sejarah pada dasarnya merupakan ilmu yang mempelajari dinamika manusia yang diikat oleh ruang dan waktu (Anis, 2014 : 487). Perubahan yang telah terjadi pada masa lampau mempengaruhi kehidupan manusia di masa sekarang ini. Perubahan tersebut bergerak dalam berbagai aspek kehidupan manusia seperti ekonomi, sosial, politik, dan budaya. Masa lalu itu sendiri adalah masa yang telah dijalani oleh suatu individu, masyarakat atau organisasi yang tentunya selalu berkaitan dengan konsepkonsep dasar yaitu ruang dan waktu.

Dengan mempelajari sejarah dapat memungkinkan manusia zaman sekarang mengetahui kesalahan-kesalahan yang telah dibuat manusia pada masa lalu atau juga mengetahui kunci keberhasilan para pendahulu. Saat kita dapat mengetahui kelemahan dan kekurangan di masa lampau, maka akan berguna agar manusia zaman sekarang tidak 
mengulanginya lagi di masa sekarang dan di masa yang akan datang. Manusia perlu belajar sejarah karena dengan demikian sejarah mengajarkan kita untuk tidak mengulangi kesalahan yang sama. Tentu saja sejarah tidak hanya membicarakan tentang kebaikan tetapi juga mengenai keburukan-keburukan yang telah dilakukan, maka manusia zaman sekarang bisa mengambil kebaikan dan mengesampingkan keburukan.

Seiring dengan pekembangan zaman yang ditandai dengan pesatnya perkembangan teknologi dan informasi ditambah dengan pandangan yang merasuki sikap masyarakat, tentang hidup adalah masa kini dan masa akan datang yang mengabaikan masa lalu, sehingga memunculkan nilai-nilai baru yang berpengaruh besar terhadap tatalaku hidup bangsa Indonesia (Anis, 2015: 54)

\section{KESADARAN DAN PENANAMAN NILAI-NILAI SEJARAH}

Kesadaran sejarah dalam pendidikan harus selalu dipupuk dan dipelajari karena urusan adalah kesadaran berbangsa dan bernegara. Jika tidak menghargai para pahlawan bisa jadi mereka tidak pancasilais dan buat apa menjadi mereka menjadi warga negara Indonesia. Kesadaran sejarah adalah menghargai nilai kepahlawanan (Anis, 2016 : 493). Pelajaran sejarah memiliki nilai yang sangat penting untuk mengembangkan inspirasi agar dapat mengembalikan martabat bangsa Indonesia sebagai bangsa yang besar dan juga mengembangkan kreativitas. Maka dari itu guru-guru sejarah perlu menyadari, dimulai dari apa yang mereka ajarkan, dapat mengembangkan kreativitas dan inovasi, bagaimana mereka memecahkan permasalahan sebagaimana teladan dari para pendahulu yang kini telah gugur mendahului.

Penanaman dan rekonstruksi sejarah akhirnya menjadi sangat penting agar supaya memperkokoh rasa nasionalisme. Nasionalisme sendiri merupakan satu kesadaran suatu bangsa yang memiliki tujuan yang sama dengan semangat kebangsaan yaitu untuk mempertahankan, mengabadikan identitas, berintegritas, kemakmuran dan kekuatan bangsa ini, yang mana merupakan hal yang perlu untuk ditekankan kepada rakyat Indonesia. Salah satu cara efektif dan menjadi penguat nasionalisme bangsa yaitu dengan melalui pembelajaran sejarah. Mata pelajaran sejarah kemudian dapat menjadi benteng yang efektif untuk memberikan semacam penyadaran agar perilaku yang menyimpang dapat diarahkan pada hal-hal yang sifatnya positif.

Fakta bahwa terjadinya kesenjangan sosial yang besar antara si kaya dan si miskin disebabkan karena persaingan bebas dalam sistem globalisasi ekonomi yang dapat menimbulkan pertentangan hebat antara yang kaya dan yang miskin sehingga nantinya berdampak pada kehidupan nasional bangsa. Ditambah lagi munculnya sikap individualisme yang dapat memunculkan sikap ketidakpedulian antar perilaku sesama warga yang berdampak kepada ketidakpeduliaan seseorang terhadap kehidupan suatu bangsa. Selain itu juga, di Indonesia yang sangat beragam baik itu etnis, suku, ras, dan agama kemudian sangat beresiko akan terjadinya salah paham yang dapat berujung kepada pertikaian.

Dengan melakukan pemupukan nasionalisme, ditambah pula substansi memiliki rasa cinta pada tanah air atau patriotisme, juga mempunyai rasa kebanggaan menjadi 
masyarakat Indonesia, mendahulukan kepentingan bersama daripada kepentingan pribadi maupun golongan, merupakan elemen yang sudah semestinya harus ada dalam kehidupan masyarakat multikultural. Mengedepankan sikap toleransi karena keberagaman yang ada di Indonesia ini, bersedia membela dan terus memajukan negara, membangun rasa kekeluargaan baik itu persaudaraan, solidaritas, kedamaian dan anti kekerasan terhadap antarkelompok, hal-hal ini sudah menjadi modal dasar yang harus secara terus-menerus dipupuk. 


\section{SIMPULAN}

Dengan selalu dan tak henti-hentinya mempelajari sejarah, maka membuat manusia dapat bergerak dari zaman ke zaman lainnya mengetahui kesalahankesalahannya di masa lampau, bahkan juga mengetahui kunci keberhasilan para pendahulu. Mengetahui kelemahan dan kekurangan di masa silam berguna agar manusia zaman sekarang tidak mengulangi lagi di masa sekarang dan masa mendatang. Manusia perlu belajar sejarah karena mengajarkan untuk tidak mengulangi kesalahan yang sama. Sejarah tidak hanya tentang kebaikan tetapi juga tentang keburukan. Maka manusia zaman sekarang bisa mengambil kebaikan dan menghilangkan keburukannya. Bapak Proklamator kitam, Soekarno pernah berkata: "Pengalaman adalah guru, adalah pedoman, adalah kemudi yang sangat berharga. Pengalaman yang tidak diperhatikan akan menghantam roboh kita sendiri”. 


\section{REFERENSI}

Anis, M.Z.A. (2016). Sejarah, Kesadaran Sejarah dan Pupusnya Identitas Nasional. In: Developing Education Based on Nationalism Values: The Proceeding of International Seminar Building Education Based on Nationalism Values

Anis, M.Z.A. (2014). Sejarah, Pendidikan Sejarah dan Pendidikan Karakter Dialog Yang Tidak Pernah Dituntaskan. In: Building Nation Character Through Education: Proceeding International Seminar on Character Education.

Anis, M.Z.A. (2015). Sejarah Bukan Warisan Melainkan Pembelajaran. Banjarmasin : Program Studi Pendidikan Sejarah FKIP Universitas Lambung Mangkurat 